\title{
Criteria and markers for protein quality assessment - a review
}

\author{
Daniel Tome* \\ AgroParisTech, Department of Life Sciences and Health, UMR 914 Nutrition physiology and ingestive behavior, \\ 16 rue Claude Bernard 75005 Paris, France
}

(Submitted 11 August 2011 - Final revision received 27 October 2011 - Accepted 28 October 2011)

\begin{abstract}
Dietary proteins are found in animal products, plant products and single-cell organisms. Proteins are present in variable proportions in these different food sources and the different proteins also differ in their amino acid composition, dietary indispensable amino acid content and physico-chemical properties. Different criteria can be used to define dietary protein requirements and different markers can be used to assess nutritional protein quality according to the criteria used for protein requirement estimation. The current approach to determining protein requirements is related to nitrogen balance and the dietary indispensable amino acid score approach relates protein quality to the capacity of protein to allow reaching nitrogen balance by providing nitrogen and indispensable amino acids. A second approach considers more directly protein nitrogen utilization by the body and includes measurement of protein digestibility and of the efficiency of dietary nitrogen retention at maintenance or for protein deposition at the whole body level or in more specific body areas. Another approach is related to protein turnover and protein synthesis in relation to maintenance and/or efficiency for deposition or development (growth) at the whole body level or for different and more specific target tissues such as muscle or bone. Lastly, protein quality can also be evaluated from different markers used as risk factors for metabolic dysfunction and disorders related for instance to insulin resistance, diabetes and obesity or cardio-vascular disease. The accuracy and relevance of these different approaches is discussed regarding the capacity of the different protein sources (i.e. animal as meat, milk or eggs, legume as soya or pea, or cereal as wheat or rice) to satisfy protein requirements according to these different criteria and markers.
\end{abstract}

Dietary protein supplies the body with nitrogen and amino acids, including the nine amino acids classified as dietary indispensable in humans (histidine, isoleucine, leucine, lysine, methionine, phenylalanine, threonine, tryptophan, and valine). Dietary proteins are found in animal products, plant products and single-cell organisms. Proteins are present in variable proportions in the different food sources and the different proteins also differ in their amino acid composition and dietary indispensable amino acid content. Amino acids are used through proteogenic pathways for the specific synthesis of body proteins and through non proteogenic pathways as precursors of other non-protein nitrogenous substances like peptide hormones, neurotransmitters, nucleic acids, glutathione, nitrogen monoxide or creatine. In addition, amino acids can be subjected to deamination and their carbon skeleton used in different energy metabolic pathways either directly as energy substrate or indirectly through gluconeogenesis. Protein nutritional quality is related to the capacity of these different protein food sources to achieve the different functions associated with the supply of nitrogen and amino acids in the body. In practice, different markers and approaches can be used to assess the nutritional quality of these different dietary proteins. A first group of approaches mainly related to nitrogen retention and nitrogen balance includes indispensable amino acid score, net protein utilisation and nitrogen efficiency for infant growth. Another group of approaches related to functional and metabolic responses to protein ingestion includes specific metabolism of target tissues (particularly muscle and bone) and/or specific responses of hormones (particularly insulin and related hormones). These markers take into account the different and specific metabolic function of nitrogen and amino acids related to both the proteogenic and the non proteogenic pathways whereas they do not consider the less specific role of amino acids in energy metabolic pathways.

\section{Protein sources and dietary indispensable amino acid content: the protein-digestibility-corrected amino acid score (PDCAAS)}

The nutritional value of dietary proteins can be related to their ability to meet nitrogen and dietary indispensable amino acid requirements in order to balance daily nitrogen losses for tissue maintenance and for the synthesis of non protein nitrogenous substances and to allow additional protein deposition in newly formed tissues for growth (in infants) and in 
specific physiological conditions such as pregnancy or lactation. Accordingly, the content and utilisation of dietary indispensable amino acids is considered as a valuable criterion for the evaluation of dietary protein as related to the capacity of a protein source provided at the mean level of protein requirement to satisfy the dietary indispensable amino acid requirement.

The protein requirement of adults has been defined as the lowest protein intake that will allow nitrogen equilibrium (zero nitrogen balance) ${ }^{(1)}$. For an adult the mean protein requirement and the safe protein requirement is $0.66 \mathrm{~g} / \mathrm{kg} / \mathrm{d}$ and $0.83 \mathrm{~g}$ protein $/ \mathrm{kg} / \mathrm{d}$, respectively and average requirements have also been defined for each of the 9 dietary indispensable amino acids $^{(1,2)}$. In addition, specific values for different selected age groups have been determined for protein and amino acid requirements using a factorial approach. The reference patterns of amino acids ( $\mathrm{mg} / \mathrm{g}$ protein) are calculated for the selected age groups by dividing the requirement for each amino acid ( $\mathrm{mg}$ amino acid $/ \mathrm{kg} \mathrm{bw} / \mathrm{d}$ ) by the average requirement for protein $\left(\mathrm{g} / \mathrm{kg}\right.$ bw/d) $(\text { Table } 1)^{(1)}$. These indispensable amino acid reference patterns are used in the assessment of protein quality according to the chemical score and PDCAAS approach. Accordingly, in the amino acid score the dietary indispensable amino acid composition of the dietary protein is compared to the reference pattern which is assumed to meet requirements for dietary indispensable amino acids when the protein is provided at the mean level of protein requirement for the selected age groups. The ratio between the content in a protein and the content in the reference pattern is determined for each indispensable amino acid and the lowest value is used as the score. The PDCAAS corrects the amino acid score by the digestibility of the protein. A PDCAAS $<1$ indicates that at least one amino acid is limiting whereas a score $\geq 1$ indicates that there is no limiting amino acid in the food or diet. Scores above $100 \%$ should by definition be truncated to $100 \%$, because any amino acid in excess of what is required is catabolized.

As reported in Table 2, dietary protein digestibility is relatively high in humans from $97 \%$ to $86 \%$ for egg and wheat, respectively. For adults, animal proteins like egg, milk product or meat have no limiting dietary indispensable amino acid whereas sulphur-containing amino acids (methionine and cysteine) are close to limiting for legume proteins such as soya protein, and lysine is the limiting amino acid for cereal proteins such as rice and wheat. In young infants, due to higher amino acid requirements than for adults, the PDCAAS values are usually lower than for adults with limiting amino acids being according to the protein sources: lysine, sulphurcontaining amino acids (methionine and cysteine), threonine and tryptophan ${ }^{(3)}$. For young infants, cooked bean products not combined with cooked rice are for instance co-limiting in methionine plus cysteine and in tryptophan and bean products combined with rice are co-limiting in isoleucine and tryptophan and marginally limiting in lysine and valine whereas the methionine plus cysteine pattern is increased in diets containing rice ${ }^{(4)}$. Overall, with PDCAAS truncated to $100 \%$ the value of proteins is in the order: animal protein (meat, milk, egg) $\geq$ legume (soya) protein $>$ cereal protein. However, truncation can limit the information on the potency of a specific protein source to balance inferior proteins in mixed diets, and this may be particularly discussed in relation to the comparison of the value for animal protein (meat, milk, egg) and legume (soya) proteins. In this case the PDCAAS are equivalent when the score is truncated to $100 \%$ but not when used as absolute values.

\section{Protein source and efficiency of protein and nitrogen utilization}

The nutritional efficiency of a protein can be determined from the extent to which dietary protein nitrogen is absorbed and retained by the organism and is able to balance daily nitrogen losses and to allow additional protein deposition in newly formed tissue for growth and in a specific physiological state such as pregnancy or lactation. The Net Protein Utilization (NPU) is the percentage of ingested nitrogen that is retained in the body and is determined by measuring digestive, metabolic (urinary) and miscellaneous nitrogen losses. NPU values are true or apparent depending on whether the loss of endogenous nitrogen is taken into account or not and this is critical to precisely determine the efficiency of dietary protein utilization and the quality of the different dietary protein sources. Endogenous intestinal (faecal) and metabolic (urinary) nitrogen losses can be obtained after feeding a protein-free diet or derived from the y-intercept of the regression line relating $\mathrm{N}$ intake to retention at different levels of protein intake, or can be directly determined from experiments using labeled amino acid or dietary proteins ${ }^{(5,6)}$.

Table 1. Scoring pattern (dietary indispensable amino acid reference profiles) for infants, children, adolescents and adults ${ }^{(1)}$

\begin{tabular}{lcccccc}
\hline & \multicolumn{5}{c}{ Infants, children, adolescents (mg/g protein) } \\
\cline { 2 - 5 } & 0.5 years & $1-2$ years & $3-10$ years & $11-14$ years & $15-18$ years & Adults (mg/g protein) \\
\hline Histidine & 20 & 18 & 16 & 16 & 16 & 15 \\
Isoleucine & 32 & 31 & 31 & 30 & 30 & 30 \\
Leucine & 66 & 63 & 61 & 60 & 60 & 59 \\
Lysine & 57 & 52 & 48 & 48 & 47 & 45 \\
Methionine + cysteine & 28 & 26 & 24 & 23 & 23 & 22 \\
Phenylalanine + tyrosine & 52 & 46 & 41 & 41 & 40 & 30 \\
Threonine & 31 & 27 & 25 & 25 & 24 & 6 \\
Tryptophan & 8.5 & 7.4 & 6.6 & 6.5 & 6.3 & 3 \\
Valine & 43 & 42 & 40 & 40 & 40 & 39 \\
\hline
\end{tabular}


Table 2. True digestibility and PDCAAS values of dietary proteins in the human adult and 6-month-old to 5 -year-old infants ${ }^{(1,3,42)}$

\begin{tabular}{|c|c|c|c|c|c|}
\hline \multirow{2}{*}{ Protein source } & \multicolumn{2}{|c|}{ True digestibility \% } & \multicolumn{2}{|c|}{ PDCAAS $\%$} & \multirow[b]{2}{*}{ Limiting amino acids } \\
\hline & Fecal & Ileal & human adult & 6 months to 5 year infant & \\
\hline \multicolumn{6}{|c|}{ Animal-source foods } \\
\hline Egg & 97 & & 130 & 118 & - \\
\hline Milk, cheese & & 95 & 130 & $112-121$ & - \\
\hline Whey protein & & 97 & 130 & $114-161$ & - \\
\hline Meat, fish & 94 & & 140 & $92-94$ & Branched chain AA \\
\hline \multicolumn{6}{|c|}{ Vegetable-source foods } \\
\hline Soya & & 91 & 99 & $90-93$ & Met + Cys \\
\hline Rice & 88 & & 55 & $44-57$ & Lys \\
\hline Wheat & & 86 & 54 & $35-52$ & Lys \\
\hline Maize & 85 & & 58 & 52 & Lys \\
\hline
\end{tabular}

As the post-prandial phase is critical for dietary protein utilization, the immediate retention of dietary nitrogen following meal ingestion represents a reliable approach for the assessment of protein nutritional efficiency. In the protein postprandial utilization approach the true dietary protein nitrogen retention has been directly measured in the post-prandial phase from experiments using $15 \mathrm{~N}$-labelled dietary proteins or 13C-labelled leucine infusion ${ }^{(5,7)}$. An average value of $70 \%$ can be considered for NPU of dietary proteins ${ }^{(8)}$ when determined in such optimized controlled conditions in healthy adults but it can be modified by different factors including the diet and the physiological conditions. Comparison of the immediate post-prandial nitrogen utilization of different protein sources in adults adapted to an adequate level of protein intake shows values for post-prandial protein utilization ranging from $75-93 \%$ to values of $63-66 \%$ for high quality proteins such as milk protein and proteins with lower quality such as wheat, respectively (Table 3). Interestingly, it appears that these values are better related to PDCAAS when not truncated to $100 \%$, more particularly when comparing milk protein and legume protein. In addition, both the quality of protein and the previous adaptation of protein intake affect the distribution and metabolic use of dietary amino acids in splanchnic (intestine, liver, etc) and peripheral (muscle, skin, etc) tissues. Both the amino acid profile of the protein and the kinetics of amino acid delivery to the blood can modulate the postprandial splanchnic and peripheral uptake of amino acids in humans ${ }^{(9,10)}$. Increasing protein intake increases splanchnic catabolic use, and splanchnic catabolic use and peripheral anabolic use are inversely affected ${ }^{(11)}$ (Fig. 1). Interestingly, this approach shows a nutritional value of proteins in the order: animal protein (milk) >legume (soya, pea) protein $>$ cereal protein (wheat).

Table 3. Protein quality and Postprandial Protein (nitrogen) Utilization (NPPU ${ }^{(5,8)}$ PPU) ${ }^{(7)}$ in the healthy adult

\begin{tabular}{lccc}
\hline$\%$ & NPPU & PPU & PDCAAS \\
\hline Milk & 75 & 93 & $110-125$ \\
Soya & 71 & - & $90-100$ \\
Pea & 71 & - & $90-98$ \\
Wheat & 66 & 63 & $35-57$ \\
\hline
\end{tabular}

An average value of $70 \%$ was initially used for the protein efficiency of diets for both maintenance and additional protein deposition in newly formed tissue for growth and in specific physiological states such as pregnancy or lactation ${ }^{(12)}$. However, from nitrogen balance studies, an average NPU value of $47 \%$ was derived for healthy adults at maintenance and no differences were found between the results when the data were grouped by sex, diet, or climate ${ }^{(1,13)}$. There are also different values used for efficiency of protein utilization for maintenance and for tissue deposition/growth in different populations and age groups including infants, pregnant or lactating women. From nitrogen balance studies, the protein quality of isolated soya protein appears to be comparable to that of animal protein sources such as milk and beef in adult humans ${ }^{(14-16)}$. In contrast, in preschool children soyabean protein isolate has a nutritive value of $82 \%$ compared with skim milk as deduced from the amount of nitrogen needed to retain $24 \mathrm{mg}$ nitrogen $/ \mathrm{kg} /$ day based on regression

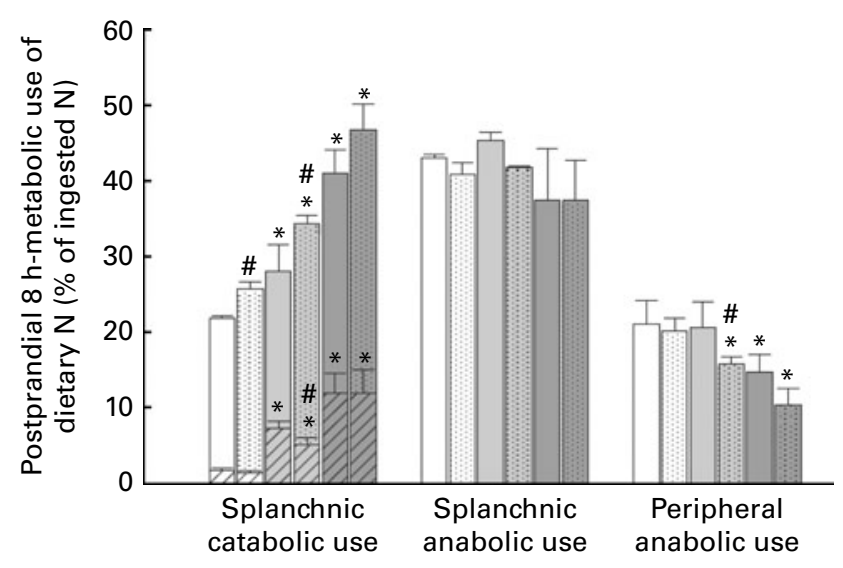

Fig. 1. Post-prandial $8 \mathrm{~h}$ metabolic use of dietary nitrogen in adults after adaptation to and its modulation by both the protein source in the meal and the habitual protein intake, normal protein (NP $1 \mathrm{~g} / \mathrm{kg} / \mathrm{d}$ ) and high protein (HP $2 \mathrm{~g} / \mathrm{kg} / \mathrm{d}$ ) diets ${ }^{(11)}$. Subjects in the milk, soya, and wheat groups twice ingested a mixed milk, soya, or wheat protein meal providing $4.85 \mathrm{mmol} \mathrm{N} / \mathrm{kg}$ body weight, respectively, the first time after a normal protein diet adaptation (NP-milk, NP-soya, and NP-wheat groups, respectively) and the second time after high-protein diet adaptation (HP-milk, HP-soya, and HP-wheat groups, respectively). Open bars denote postprandial utilization of meal nitrogen for splanchnic catabolic, splanchnic anabolic, and peripheral anabolic purposes at $8 \mathrm{~h}$. Hatched bars denote meal nitrogen enterohepatic recycling into the metabolic nitrogen pool through urea hydrolysis at $8 \mathrm{~h}$. 
of apparent nitrogen balance that was $0.61 \mathrm{~g}$ and $0.75 \mathrm{~g}$ for skim milk and soyabean protein isolate, respectively ${ }^{(17)}$. In agreement with the indispensable amino acid scoring approach, the protein quality can be improved by mixing protein sources that can compensate for their individual deficiencies. Accordingly, in preschool children a corn-bean mixture ( $76 \%$ corn, $24 \%$ beans) or addition of cereal to the diet can satisfy all nitrogen balance requirements ${ }^{(18,19)}$. From these results the nutritional quality can be classified as: animal protein (milk, meat) $\geq$ legume (soya) protein $>$ cereal protein (wheat, corn).

Adequate dietary protein intake has been associated with adequate growth in infants. Milk protein is the main protein source for infant formulas and is usually used as a reference. Alternative protein sources include soya, other legumes and cereal proteins and different nutritional or pathological conditions are considered including normal healthy conditions, under-nutrition and allergy (mainly cow milk allergy) (Table 4). Soya protein formulas ensure normal growth and development in healthy term infants but have no nutritional advantages over cow's milk protein formulas and are considered if tolerance to soya protein is established with main indications including severe lactose intolerance, galactosaemia and the need to avoid foods of animal origin ${ }^{(20-22)}$. Lentilbased high protein diets also appeared comparable to animal-based diets in respect to nitrogen absorption and nitrogen balance in malnourished children ${ }^{(24)}$. Rice is among the first solid foods fed to infants in many cultures. Rice, as other cereals, is limiting in total protein as compared with dairy and other grain/legume protein sources, and is rich in methionine and cystine and is deficient in lysine and threonine. Fortification of rice protein with these two limiting amino acids improves its protein quality. Hypo-allergenicity efficacy, particularly for hydrolyzed rice protein-based formulas, has been reported, but limited data indicate that rice protein based infant formula may provide a potentially adequate alternative if standard milk- or soya protein-based formulas are not tolerated ${ }^{(29)}$. In addition, Quality protein maize that consists of maize varieties bio-fortified with lysine and tryptophan could be used in preschool diets and could reduce or prevent growth faltering and may in some cases support catch-up growth in body weight ${ }^{(30)}$. From these results the nutritional quality can be classified as: animal protein $($ milk, meat) $\geq$ legume (soya) protein $>$ cereal protein (wheat, corn, rice).

\section{Protein intake and response of target tissues (muscle, bone) and hormones (insulin, IGF1)}

An increasing number of studies address the question of the role of protein in promoting optimal health at intakes beyond the recommended requirement, e.g. in relation to weight management and satiety, sarcopenia, bone health or insulin and glucose homeostasis. More particularly in older subjects it is questioned as to whether an increase in amino acid and protein availability could improve bone and muscle mass.

Increasing the intake of protein and the branched-chain amino acid leucine above the recommended requirement has been suspected to improve muscle mass. The major anabolic influences on muscle are feeding and contractile activity, and ingestion of sufficient dietary protein is required for muscle protein synthesis and maintenance. Amino acids are key components in promoting postprandial protein anabolism and skeletal muscle mass and contractility and the availability of amino acids is crucial for net anabolism in muscle. Dietary proteins, when ingested, result in systemic hyper amino acidaemia that supports muscle protein synthesis. In vivo, amino acids display an anabolic effect and have been shown to stimulate muscle protein synthesis ${ }^{(31,32)}$. In addition,

Table 4. Protein source and determined efficiency of utilization for growth in preschool infants

\section{Healthy infants}

Growth of newborn, term infants fed soya formulas or mixed feeding

Partially hydrolyzed rice protein-based infant formula fortified with lysine and threonine in healthy infants 2 to 16 weeks of age.

\section{Malnourished infants}

Lentil-based and animal-based protein diet in moderately malnourished 24 to 59 month old children convalescing from shigellosis

High protein rice flour, with added lysine and threonine, in recovering malnourished infants

Cow milk allergy

Soya formula or hydrolyzed whey formula

Soya-based formula, rice-hydrolysate formula and hydrolysed casein formula

Soyaprotein formula and Rice-hydrolysate Formula

Rice-hydrolysate formula supplemented with lysine and threonine and hydrolysed cow milk protein formula Similar growth as with soya formulas or mixed feeding in the first
year

Normal growth comparable to infants fed a standard intact milk protein based formula

Similar nitrogen balance between Lentil-based and animal-based protein diet

$\mathrm{N}$ retention equal to that from casein

Similar Weight-for-length and length growth with soya formula or hydrolyzed whey formula

Raises doubts about the nutritional adequacy of rice-hydrolysate formulas

No significant difference between soya protein and rice hydrolysate for weight and length-for-age z-score

No significant difference between Rice-hydrolysate and hydrolysed cow milk protein formula for weight and length-for-age z-score 
the branched chain amino acids (BCAA) (leucine, valine, isoleucine) and particularly leucine have been demonstrated to act as a signal for muscle protein synthesis both in vitro and in vivo in animal models ${ }^{(33)}$. Interestingly, compared to casein and cod protein, peanut protein intake alters body composition by reducing skeletal muscle mass and liver weight as well as muscle contractility and lipid metabolism in the rat, an effect that could originate from the relatively low leucine content of this protein ${ }^{34)}$.

However, there is no result showing that a dietary protein level above the recommended requirement of $0 \cdot 8-1 \mathrm{~g} / \mathrm{kg} / \mathrm{d}$ can further modulate skeletal protein mass in non-exercising young healthy human subjects. There was no effect of a dietary protein intake above the average requirement on muscle mass and protein content and a high protein diet has not been demonstrated to modulate skeletal protein mass in non-exercising human subjects or animals ${ }^{(35,36)}$. Moreover, in adult humans there is no clear evidence that chronic leucine supplementation above the requirement as previously defined (i.e. $39 \mathrm{mg} / \mathrm{kg} \mathrm{bw} / \mathrm{d}$ in adult) is efficient in promoting muscle mass in non exercising subjects ${ }^{(37)}$. In older adults several studies concluded that the protein requirement may be greater than that for younger adults particularly in association with inactivity ${ }^{(39-41)}$. This was particularly deduced from an assumed lower efficiency of protein utilisation in the elderly ${ }^{(42)}$. However, other studies did not show differences between young and elderly subjects after assessment of nitrogen balance ${ }^{(43)}$. In contrast, with the added stimulus of resistance exercise, muscle protein synthesis is stimulated and this anabolic effect is enhanced by increasing the availability of amino acids and protein which appear to be better than energy alone (as carbohydrate) ${ }^{(44)}$. In some studies whey protein appears to be more efficient than casein and soya protein ${ }^{(45,46)}$ but the difference between whey protein and casein was not confirmed ${ }^{(47)}$. Some authors also found that in older adults an increase in dietary protein alone does not change body composition or improve lean body mass unless accompanied by physical training programs ${ }^{(48,49)}$.

Protein and calcium are the main components of bone structure and it is widely accepted that protein deficiency increases the risk for bone fragility and fracture. In most epidemiological studies, bone mineral density is positively related to protein intake and this is also observed in infants, in premenopausal women and elderly people ${ }^{(50-56)}$. However, a positive relationship between protein intake above the safe level of protein intake based on nitrogen balance and the risk of bone fracture is not always significant and remains controversial $^{(57-61)}$. Whether increasing protein intake above the recommended intake further improves bone mineral density remains to be confirmed as well as the characteristics of protein quality in relation to bone health. In addition, although protein is essential for bone health, an increase in protein intake is often associated with an increase in urinary calcium excretion and it was first hypothesized that this could originate from an activation of bone resorption in order to provide calcium for the neutralization of the acid load produced by the oxidation of sulphur amino acids ${ }^{(62)}$. However, the association between protein intake and a decrease in bone mineral den- sity was not confirmed and recent studies do not confirm that increasing protein intake above the recommended intake promotes skeletal bone mineral loss ${ }^{(63-67)}$.

Protein intake and protein quality influence insulin secretion and sensitivity in adults. High protein diets are accompanied by increased stimulation of glucagon and insulin within the endocrine pancreas; high glycogen turnover and stimulation of gluconeogenesis and correlation between daily protein intake and acute insulin response to glucose (as an estimate of insulin secretion capacities) indicates that protein intake potentiates insulin secretion ${ }^{(68)}$. The acute effect of protein meals on insulin and glucose in lean men could be different according to the protein source with an effect in the order: whey protein $>$ fish protein $>$ turkey protein $>$ egg $^{(69)}$. Contradictory results have been obtained for effects of an increase in protein intake on insulin sensitivity. Some studies suggested that exposure to high levels of branched chain amino acids could have a deleterious effect on insulin signalling leading to impaired insulin sensitivity and glucose tolerance ${ }^{(32,70-72)}$. However, prolonged leucine supplementation $(7.5 \mathrm{~g} / \mathrm{d})$ in elderly type 2 diabetics habitually consuming an adequate amount of dietary protein did not modulate their glycaemic control ${ }^{(73)}$. In addition, an improvement of insulin sensitivity and glucose tolerance was reported with normal or reduced calorie high-protein diets regardless of weight loss ${ }^{(74-77)}$. In overweight or obese, post-menopausal women a casein and a whey daily supplement both improved insulin secretion, the homeostasis model assessment of insulin resistance (HOMA-IR) scores and triglycerides, and whey was more efficient than casein ${ }^{(69,78-81)}$.

Protein intake and protein quality influence IGF1 secretion in infants. Evidence increases for programming effects of early infant feeding choices on, among other factors, later obesity risk. In infants, high dietary protein intake has been associated with increased growth and this may be linked to increased concentrations of insulin-like growth factor I (IGF-I), which seem to be influenced by the diet, especially its protein component ${ }^{(82)}$. Interestingly, IGF-I and height were positively associated with intakes of animal protein, but not with the intake of vegetable protein and in addition high intakes of skimmed milk, but not meat, increased serum IGF-I and IGFBP-3 in eight-year-old boys ${ }^{(83-85)}$. Moreover, whey protein significantly affects fasting plasma levels of insulin, IGF-1 and IGF-1/IGFBP-3 whereas this effect was not observed with $\operatorname{casein}^{(86)}$.

\section{Conclusion}

Dietary proteins provide the body with nitrogen and amino acids as essential metabolic components with numerous specific metabolic functions related to both proteogenic and non proteogenic pathways. Different approaches can be used to assess dietary protein quality and properties including dietary indispensable amino acid content, nitrogen retention efficiency, nitrogen efficiency for growth, and the effect of protein intake on target tissues (muscle, bone, etc) and on insulin and related hormones. 
The current approach to determining protein requirements and measures of protein quality associate body nitrogen balance and dietary indispensable amino acid requirements and although still debated, numerous results strongly suggest that this approach take into account the different and specific metabolic functions of nitrogen and amino acids related to both the proteogenic and the non proteogenic pathways. In contrast, it probably does not include the role of amino acids as energy substrate since the different energy substrates can be for a large part substituted one to one between carbohydrate, fat and protein. Combination of dietary amino acid composition and estimates of dietary indispensible amino acid requirements lead to PDCAAS which is a measure of protein quality. In the PDCAAS reference method, scores above $100 \%$ are by definition truncated to $100 \%$, because any amino acid in excess of what is required should be catabolized. Overall, the method appears valuable to predict the nutritional efficiency of mixed diets to reach nitrogen balance. It is a relatively valuable index to predict protein quality related to the efficiency for growth in young infants.

Another current approach of protein quality evaluation relates to the efficiency of protein nitrogen utilization (NPU) determined either in acute studies (post-prandial) or more chronically (nitrogen balance). The acute measurement of post-prandial protein retention can determine the potential efficiency of the ingested protein. Interestingly, the postprandial NPU values are better related to PDCAAS not truncated to $100 \%$, more particularly when comparing milk protein and legume protein. This observation suggests that in some conditions non truncated values of PDCAAS should be considered to evaluate the potential quality of a protein source. Moreover, if an average potential value of $70 \%$ can be considered for the NPU of dietary proteins, this can be modified by different factors including the diet and the physiological conditions and this is reflected in the lower efficiency obtained more chronically by nitrogen balance studies with a lower potency to discriminate between the different protein sources.

Overall, protein quality measures derived from nitrogen balance and whole body nitrogen retention data represent the more ubiquitous evaluation of dietary protein quality whereas other criteria related to nitrogen retention in different parts of the body, the metabolic response of target tissues such as muscle and bone or the influence on hormones can be used additionally for more specific applications and specific situations (infants, exercise, older adults, etc). Some of these approaches could be of help in the future to more precisely define protein requirement and quality adapted to prevention of chronic and metabolic disease in specific sensitive populations, and particularly in infants and older adults.

\section{Acknowledgements}

The author has no conflict of interest. "This research received no specific grant from any funding agency in the public, commercial or not-for-profit sectors."

\section{References}

1. WHO/FAO/UNU (2007) Protein and Amino Acid Requirements in Human Nutrition. Report of a Joint WHO/FAO/ UNU Expert Consultation, WHO Technical Report Series, No 935.

2. Bos C, Gaudichon C \& Tomé D (2002) Isotopic studies of protein and amino acid requirements. Curr Opin Clin Nutr Metab Care 5, 55-61.

3. Michaelsen KF, Hoppe C, Roos N, et al. (2009) Choice of foods and ingredients for moderately malnourished children 6 months to 5 years of age. Food Nutr Bull 30, S343-S404, Review.

4. Kannan S, Nielsen SS \& Mason AC (2001) Protein Digestibility-Corrected Amino Acid Scores for Bean and Bean-Rice Infant Weaning Food Products. J Agric Food Chem 49, 5070-5074.

5. Fouillet H, Bos C, Gaudichon C, et al. (2002a) Approaches to quantifying protein metabolism in response to nutrient ingestion. J Nutr 132, 3208S-3218S

6. Fuller MF \& Tomé D (2005) In vivo determination of amino acid bioavailability in humans and model animals. $J A O A C$ Int 88, 923-934, Review.

7. Millward DJ, Fereday A, Gibson NR, et al. (2002) Efficiency of utilization of wheat and milk protein in healthy adults and apparent lysine requirements determined by a singlemeal [1-13C]leucine balance protocol. Am J Clin Nutr 76, 1326-1334.

8. Bos C, Juillet B, Fouillet H, et al. (2005) Postprandial metabolic utilization of wheat protein in humans. Am J Clin Nutr 81, 87-94.

9. Fouillet H, Mariotti F, Gaudichon C, et al. (2002b) Peripheral and Splanchnic Metabolism of Dietary Nitrogen are Differently Affected by the Protein Source in Humans. J Nutr 132, 125-133.

10. Deglaire A, Fromentin C, Fouillet H, et al. (2009) Hydrolyzed dietary casein as compared with the intact protein reduces postprandial peripheral, but not whole-body, uptake of nitrogen in humans. Am J Clin Nutr 90, 1011-1022.

11. Fouillet H, Juillet B, Gaudichon C, et al. (2009) Absorption kinetics are a key factor regulating postprandial protein metabolism in response to qualitative and quantitative variations in protein intake. Am J Physiol Regul Integr Comp Physiol 297, R1691-R1705.

12. FAO/WHO/UNU. (1985) Energy and protein requirements, Report of a Joint WHO/FAO/UNU Expert Consultation, WHO Technical Report Series No 724.

13. Rand WM, Pellett PL \& Young VR (2003) Meta-analysis of nitrogen balance studies for estimating protein requirements in healthy adults. Am J Clin Nutr 77, 109-127.

14. Scrimshaw NS, Wayler AH, Murray E, et al. (1983) Nitrogen balance response in young men given one of two isolated soy proteins or milk proteins. J Nutr 113, 2492-2497.

15. Wayler A, Queiroz E, Scrimshaw NS, et al. (1983) Nitrogen balance studies in young men to assess the protein quality of an isolated soy protein in relation to meat proteins. J Nutr 113, 2485-2491.

16. Young VR, Wayler A, Garza C, et al. (1984) A long-term metabolic balance study in young men to assess the nutritional quality of an isolated soy protein and beef proteins. Am J Clin Nutr 39, 8-15.

17. Torún B, Cabrera-Santiago MI \& Viteri FE (1981) Protein requirements of preschool children: obligatory nitrogen losses and nitrogen balance measurements using cow's milk. Arch Latinoam Nutr 31, 571-585. 
18. Viteri FE, Torun B, Arroyave G, et al. (1981) Use of corn-bean mixtures to satisfy protein and energy requirements of preschool children. In Protein-energy requirements of developing countries: evaluation of new data. Protein-energy requirements of developing countries, pp. 202-209 [B Torun, V Young and W Rand, editors]. Vol 1., Tokyo: United Nations University Press.

19. Shulman RJ, Gannon N \& Reeds PJ (1995) Cereal feeding and its impact on the nitrogen economy of the infant. Am J Clin Nutr 62, 969-972.

20. Turck D (2007) Soy protein for infant feeding: what do we know? Curr Opin Clin Nutr Metab Care 10, 360-365, Review.

21. Seppo L, Korpela R, Lönnerdal B, et al. (2005) A follow-up study of nutrient intake, nutritional status, and growth in infants with cow milk allergy fed either a soy formula or an extensively hydrolyzed whey formula. Am J Clin Nutr 82, $140-145$.

22. Lasekan JB, Ostrom KM, Jacobs JR, et al. (1999) Growth of newborn, term infants fed soy formulas for 1 year. Clin Pediatr (Phila) 38, 563-571.

23. Lasekan JB, Koo WW, Walters J, et al. (2006) Growth, tolerance and biochemical measures in healthy infants fed a partially hydrolyzed rice protein-based formula: a randomized, blinded, prospective trial. J Am Coll Nutr 25, 12-19.

24. Hossain MI, Islam MM, Wahed MA, et al. (2009) Lentil-based high protein diet is comparable to animal-based diet in respect to nitrogen absorption and nitrogen balance in malnourished children recovering from shigellosis. Asia Pac J Clin Nutr 18, 8-14.

25. Gastañaduy A, Cordano A \& Graham GG (1990) Acceptability, tolerance, and nutritional value of a rice-based infant formula. J Pediatr Gastroenterol Nutr 11, 240-246.

26. Savino F, Castagno E, Monti G, et al. (2005) Z-score of weight for age of infants with atopic dermatitis and cow's milk allergy fed with a rice-hydrolysate formula during the first two years of life. Acta Paediatr Suppl 94, 115-119.

27. D'Auria E, Sala M, Lodi F, et al. (2003) Nutritional value of a rice-hydrolysate formula in infants with cows' milk protein allergy: a randomized pilot study. J Int Med Res 31, 215-222.

28. Reche M, Pascual C, Fiandor A, et al. (2010) The effect of a partially hydrolysed formula based on rice protein in the treatment of infants with cow's milk protein allergy. Pediatr Allergy Immunol 21, 577-585.

29. Koo WW \& Lasekan JB (2007) Rice protein-based infant formula: current status and future development. Minerva Pediatr 59, 35-41.

30. Akalu G, Taffesse S, Gunaratna NS, et al. (2010) The effectiveness of quality protein maize in improving the nutritional status of young children in the Ethiopian highlands. Food Nutr Bull 31, 418-430.

31. Bohe J, Low A, Wolfe RR, et al. (2003) Human muscle protein synthesis is modulated by extracellular, not intramuscular amino acid availability: a dose-response study. J Physiol 552, 315-324.

32. Nair KS \& Short KR (2005) Hormonal and signaling role of branched-chain amino acids. J Nutr 135, 1547S-1552S.

33. Balage M \& Dardevet D (2010) Long-term effects of leucine supplementation on body composition. Curr Opin Clin Nutr Metab Care 13, 265-270.

34. Jacques H, Leblanc N, Papineau R, et al. (2010) Peanut protein reduces body protein mass and alters skeletal muscle contractile properties and lipid metabolism in rats. Br J Nutr 103, 1331-1339.

35. Bolster DR, Pikosky MA, Gaine PC, et al. (2005) Dietary protein intake impacts human skeletal muscle protein fractional synthetic rates after endurance exercise. $A m$ J Physiol Endocrinol Metab 289, E678-E683.

36. Chevalier L, Bos C, Gryson C, et al. (2009) High-protein diets differentially modulate protein content and protein synthesis in visceral and peripheral tissues in rats. Nutrition $\mathbf{2 5}$, 932-939.

37. Koopman R, Wagenmakers AJ, Manders RJ, et al. (2005) Combined ingestion of protein and free leucine with carbohydrate increases postexercise muscle protein synthesis in vivo in male subjects. Am J Physiol Endocrinol Metab 288, E645-E653.

38. Hays NP, Kim H, Wells AM, et al. (2009) Effects of whey and fortified collagen hydrolysate protein supplements on nitrogen balance and body composition in older women. $\mathrm{J} \mathrm{Am}$ Diet Assoc 109, 1082-1087.

39. Gaffney-Stomberg E, Insogna KL, et al. (2009) Increasing dietary protein requirements in elderly people for optimal muscle and bone health. J Am Geriatr Soc 57, 1073-1079.

40. Ferrando AA, Paddon-Jones D, Hays NP, et al. (2010) EAA supplementation to increase nitrogen intake improves muscle function during bed rest in the elderly. Clin Nutr 29, 18-23.

41. Thalacker-Mercer AE, Fleet JC, Craig BA, et al. (2010) The skeletal muscle transcript profile reflects accommodative responses to inadequate protein intake in younger and older males. J Nutr Biochem 21, 1076-1082.

42. AFSSA (French Agency for Food Safety). (2007) Apport en protéines: consommation, qualité, besoins et recommandations. Report of the working group, $461 \mathrm{pp}$

43. Campbell WW, Johnson CA, McCabe GP, et al. (2008) Dietary protein requirements of younger and older adults. Am J Clin Nutr 88, 1322-1329.

44. Tang JE, Manolakos JJ, Kujbida GW, et al. (2007) Minimal whey protein with carbohydrate stimulates muscle protein synthesis following resistance exercise in trained young men. Appl Physiol Nutr Metab 32, 1132-1138.

45. Phillips SM, Tang JE \& Moore DR (2009) The role of milkand soy-based protein in support of muscle protein synthesis and muscle protein accretion in young and elderly persons. J Am Coll Nutr 28, 343-354, Review.

46. Tang JE, Moore DR, Kujbida GW, et al. (2009) Ingestion of whey hydrolysate, casein, or soy protein isolate: effects on mixed muscle protein synthesis at rest and following resistance exercise in young men. $J$ Appl Physiol 107, 987-992.

47. Reitelseder S, Agergaard J, Doessing S, et al. (2011) Whey and casein labeled with L-[1-13C]leucine and muscle protein synthesis: effect of resistance exercise and protein ingestion. Am J Physiol Endocrinol Metab 300, E231-E242.

48. Campbell \& Leidy (2007) Dietary protein and resistance training effects on muscle and body composition in older persons. J Am Coll Nutr 26, 696S-703S.

49. Iglay HB, Apolzan JW, Gerrard DE, et al. (2009) Moderately increased protein intake predominately from egg sources does not influence whole body, regional, or muscle composition responses to resistance training in older people. J Nutr Health Aging 13, 108-114.

50. Geinoz G, Rapin CH, Rizzoli R, et al. (1993) Relationship between bone mineral density and dietary intakes in the elderly. Osteoporos Int 3, 242-248.

51. Cooper C, Atkinson EJ, Hensrud DD, et al. (1996) Dietary protein intake and bone mass in women. Calcif Tissue Int 58, 320-325.

52. Tucker KL, Hannan MT \& Kiel DP (2001) The acid-base hypothesis: diet and bone in the Framingham Osteoporosis Study. Eur J Nutr 40, 231-237. 
53. Promislow JH, Goodman-Gruen D, Slymen DJ, et al. (2002) Protein consumption and bone mineral density in the elderly : the Rancho Bernardo Study. Am J Epidemiol 155, 636-644.

54. Rapuri PB, Gallagher JC \& Haynatzka V (2003) Protein intake: effects on bone mineral density and the rate of bone loss in elderly women. Am J Clin Nutr 77, 1517-1525.

55. Devine A, Dick IM, Islam AF, et al. (2005) Protein consumption is an important predictor of lower limb bone mass in elderly women. Am J Clin Nutr 81, 1423-1428.

56. Alexy U, Remer T, Manz F, et al. (2005) Long-term protein intake and dietary potential renal acid load are associated with bone modeling and remodeling at the proximal radius in healthy children. Am J Clin Nutr 82, 1107-1114.

57. Hegsted DM (1986) Calcium and osteoporosis. J Nutr 116, 2316-2319.

58. Abelow BJ, Holford TR \& Insogna KL (1992) Cross-cultural association between dietary animal protein and hip fracture: a hypothesis. Calcif Tissue Int 50, 14-18.

59. Meyer HE, Pedersen JI, Løken EB, et al. (1997) Dietary factors and the incidence of hip fracture in middle-aged Norwegians. A prospective study. Am J Epidemiol 145, 117-123.

60. Munger RG, Cerhan JR \& Chiu BC (1999) Prospective study of dietary protein intake and risk of hip fracture in postmenopausal women. Am J Clin Nutr 69, 147-152.

61. Frassetto LA, Todd KM, Morris RC Jr, et al. (2000) Worldwide incidence of hip fracture in elderly women: relation to consumption of animal and vegetable foods. J Gerontol A Biol Sci Med Sci 55, M585-M592.

62. Barzel US \& Massey LK (1998) Excess dietary protein can adversely affect bone. J Nutr 128, 1051-1053.

63. Fenton TR, Lyon AW, Eliasziw M, et al. (2009) Meta-analysis of the effect of the acid-ash hypothesis of osteoporosis on calcium balance. J Bone Miner Res 24, 1835-1840.

64. Bonjour JP, Chevalley T, Ferrari S, et al. (2009) The importance and relevance of peak bone mass in the prevalence of osteoporosis. Salud Publica Mex 51, S5-17.

65. Bilo HJ, Schaap GH, Blaak E, et al. (1989) Effects of chronic and acute protein administration on renal function in patients with chronic renal insufficiency. Nephron 53, 181-187.

66. Pye KM, Wakefield AP, Aukema HM, et al. (2009) A high mixed protein diet reduces body fat without altering the mechanical properties of bone in female rats. $J$ Nutr $\mathbf{1 3 9}$, 2099-2105.

67. Cao JJ, Johnson LK \& Hunt JR (2011) A Diet High in Meat Protein and Potential Renal Acid Load Increases Fractional Calcium Absorption and Urinary Calcium Excretion without Affecting Markers of Bone Resorption or Formation in Postmenopausal Women. J Nutr 141, 391-397.

68. Linn T, Santosa B, Grönemeyer D, et al. (2000) Effect of long-term dietary protein intake on glucose metabolism in humans. Diabetologia 43, 1257-1265.

69. Pal S \& Ellis V (2010) The acute effects of four protein meals on insulin, glucose, appetite and energy intake in lean men. Br J Nutr 104, 1241-1248.

70. Patti ME, Brambilla E, Luzi L, et al. (1998) Bidirectional modulation of insulin action by amino acids. J Clin Invest 101, 1519-1529.
71. Tremblay F \& Marette A (2001) Amino acid and insulin signaling via the mTOR/p70 S6 kinase pathway. A negative feedback mechanism leading to insulin resistance in skeletal muscle cells. J Biol Chem 276, 38052-38060.

72. Wang TJ, Larson MG, Vasan RS, et al. (2011) Metabolite profiles and the risk of developing diabetes. Nature Medicine 17, 448-453.

73. Leenders M, Verdijk LB, van der Hoeven L, et al. (2011) Prolonged leucine supplementation does not augment muscle mass or affect glycemic control in elderly type 2 diabetic men. J Nutr 141, 1070-1076.

74. Farnsworth E, Luscombe ND, Noakes M, et al. (2003) Effect of a high protein, energy restricted diet on body composition, glycemic control and lipid concentrations in overweight and obese hyperinsulinemic men and women. $A m$ J Clin Nutr 78, 31-39.

75. Layman DK, Shiue H, Sather C, et al. (2003) Increased dietary protein modifies glucose and insulin homeostasis in adult women during weight loss. J Nutr 133, 405-410.

76. Gannon MC \& Nuttall FQ (2004) Effect of a high-protein, low-carbohydrate diet on blood glucose control in people with type 2 diabetes. Diabetes 53, 2375-2382.

77. Lacroix M, Gaudichon C, Martin A, et al. (2004) A long-term high-protein diet markedly reduces adipose tissue without major side effects in Wistar male rats. Am J Physiol Regul Integr Comp Physiol 287, R934-R942.

78. Pal S \& Ellis V (2011) Acute effects of whey protein isolate on blood pressure, vascular function and inflammatory markers in overweight postmenopausal women. Br J Nutr 28, 1-8.

79. Pal S \& Ellis V (2010) The chronic effects of whey proteins on blood pressure, vascular function, and inflammatory markers in overweight individuals. Obesity (Silver Spring) 18, 1354-1359.

80. Pal S, Ellis V \& Dhaliwal S (2010) Effects of whey protein isolate on body composition, lipids, insulin and glucose in overweight and obese individuals. Br J Nutr 104, 716-723.

81. Pal S, Ellis V \& Ho S (2010) Acute effects of whey protein isolate on cardiovascular risk factors in overweight, postmenopausal women. Atherosclerosis 212, 339-344.

82. Larnkjaer A, Hoppe C, Mølgaard C, et al. (2009) The effects of whole milk and infant formula on growth and IGF-I in late infancy. Eur J Clin Nutr 63, 956-963.

83. Hoppe C, Tina Udam R, Lauritzen L, et al. (2004) Animal protein intake, serum insulin-like growth factor I, and growth in healthy 2.5-y-old Danish children. Am J Clin Nutr 80 , 447-452.

84. Hoppe C, Mølgaard C, Juul A, et al. (2004) High intakes of skimmed milk, but not meat, increase serum IGF-I and IGFBP-3 in eight-year-old boys. Eur J Clin Nutr $\mathbf{5 8}$, $1211-1216$.

85. Hoppe C, Mølgaard C \& Michaelsen KF (2006) Cow's milk and linear growth in industrialized and developing countries. Annu Rev Nutr 26, 131-173, Review.

86. Hoppe C, Mølgaard C, Dalum C, et al. (2009) Differential effects of casein versus whey on fasting plasma levels of insulin, IGF-1 and IGF-1/IGFBP-3: results from a randomized 7-day supplementation study in prepubertal boys. Eur J Clin Nutr 63, 1076-1083. 